\title{
Review Liaison
}

National Cancer Institute

\section{Source}

National Cancer Institute. Review Liaison. NCI Thesaurus. Code C51865.

A person that maintains communication between the investig ators that submit funding proposals and the officials in charge of review at the institution that fund the proposals. 